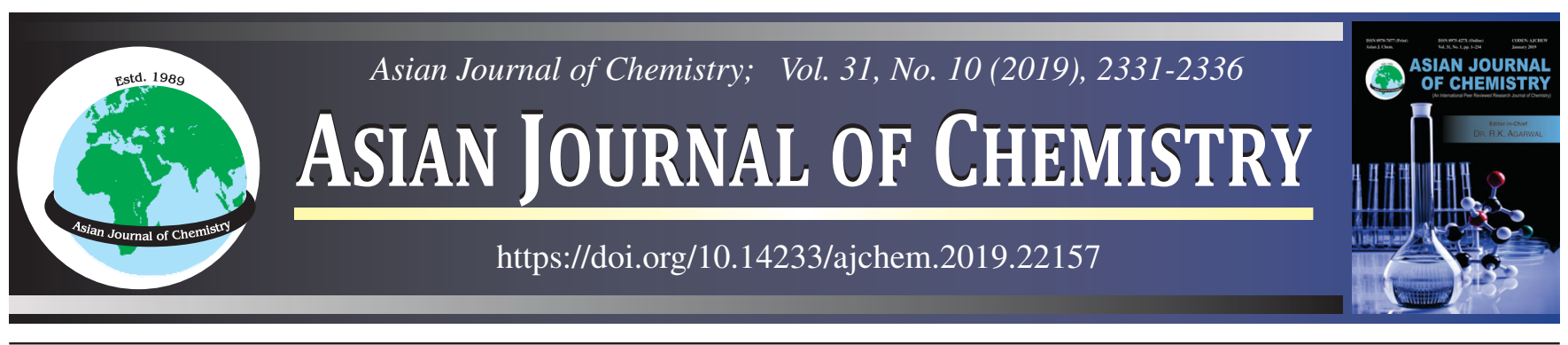

\title{
Synthesis and Spectral Investigations of Polymeric Hydrazone Schiff Base and its Transition Metal Complexes with Promising Antimicrobial, Anti-Angeogenic and DNA Photo-Cleavage Activities
}

\author{
Manoj Kumar ${ }^{1, *}$, Anita Rani ${ }^{1}$, Hardeep Singh Tuli ${ }^{2}$, Rajshree Khare ${ }^{3}$ and Vinit Parkash ${ }^{1}$
}

${ }^{1}$ Department of Chemistry, Maharishi Markandeshwar University, Sadopur, Ambala-134003, India

${ }^{2}$ Department of Biotechnology, Maharishi Markandeshwar (Deemed to be University), Mullana, Ambala-133207, India

${ }^{3}$ Department of Chemistry, Maharishi Markandeshwar (Deemed to be University), Mullana, Ambala-133207, India

*Corresponding author: E-mail: manojraju27@gmail.com

Received: 29 April 2019;

Accepted: 10 June 2019;

Published online: 30 August 2019;

AJC-19546

This report describes the synthesis and exploration of novel Schiff base ligand in the form of a polymer (heptamer) which was prepared by reaction between 3,4-diacetyl-2,5-hexanedione and hydrazine hydrate in ethanol. On further reaction of Schiff base with transition metals ions $(\mathrm{Co}$ and $\mathrm{Cu}$ ) leads to formation of its transition metal complexes. The structural identification of Schiff base ligand and its transition metal complexes were characterized by classical structural techniques like FT-IR, NMR and mass spectra. The free ligand and | its transition metal complexes have been screened for in vitro biological activities against various strains of bacteria and fungi. The prepared Schiff base and its metal complexes were also screened for antiangiogenic activity. The results have shown the remarkable antimicrobial and antiangiogenic activities of the Schiff base and its metal complexes.

| Keywords: 3,4-Diacetyl-2,5-hexanedione, Hydrazine hydrate, Antimicrobial activity, DNA-photocleavage.

ᄂ _ - - - - - - - - - - - - - - - - - - - - - - - - - - - - - - -

\section{INTRODUCTION}

The Schiff bases with donor atoms particularly nitrogen atoms were investigated very well in the recent years due to their excellent chelating capabilities with various metal ions and their biological importance. Large number of co-ordination compounds has various applications in different fields [1-3]. The Schiff base itself have some antimicrobial activity which have been increased many folds by complexation with transition metals [4]. Schiff bases and their transition metal complexes are usually considered one of the most important biologically active chemical compounds. The imine bonds of Schiff bases are also found in different enzymes such as transaminase, transketolases and tryptophan.

Hydrazones form an interesting class of compounds which find extensive application in different areas $[5,6]$. The metal hydrazone complexes attracted a considerable attention due to their good biological activities and chemical versatility. They form a special group of compounds in Schiff base family which are characterized by presence of two interlinked nitrogen atoms.
The hydrazones of acyl, aroyl and heteroacroyl compounds have an additional donor sites which make them more flexible and versatile. The coordination behaviour of hydrazones has been well studied and depends on the $\mathrm{pH}$ medium, nature of the substituents and also on the position of hydrazone group relative to other moieties. As biologically active compound $[7,8]$ hydrazone find a remarkable application to cure tumor [9], cytotoxic [10], antiproliferative, antibacterial, antiviral, antifungal [11-14], tuberculosis, leprosy, along with some mental diseases [15-17]. Hence many important enzymatic reactions catalyzed by the transition metal complexes take place only due to presence of Schiff bases [18,19]. The copper(II) complexes of hydrazones are known to possess antitumor [20] and bacteriostatic properties [21]. However, the biological activity and the applications of Schiff bases and their metal complexes depend to a large extent on their molecular structure and the type of metal ions with which it coordinates.

Heterocyclic compounds in which oxygen, sulphur and nitrogen atoms are present play an important role owing to their remarkable high antimicrobial, antiviral and antifungal

This is an open access journal, and articles are distributed under the terms of the Attribution 4.0 International (CC BY 4.0) License. This license lets others distribute, remix, tweak, and build upon your work, even commercially, as long as they credit the author for the original creation. You must give appropriate credit, provide a link to the license, and indicate if changes were made. 
properties [22] and anti-HIV activity [23]. Recent researches [24] have proved the anticarcinogenic potential of modified hydrazide derivatives in very small dose. The Schiff base made from hydrazide induces the death of neoplastic cell without harming healthy cells. Hence Schiff base complexes are now days known to be among the most important stereochemical models in main group and coordination chemistry. They possess this characterstics due to their preparative accessibility and structural variety. The high affinity of transition metals toward Schiff base is utilized in prepration of their solid complexes. Similarly polymeric Schiff bases are also an important class of ligands and their transition metal complexes are more potent in co-ordination chemistry [25-27]. Coordination polymers are defined as materials in which metal ions are linked together with di- or poly-functional ligands and are thermally stable $[28,29]$. A large number of articles have published on the coordination chemistry of polymeric Schiff base complexes [3032], which exhibit a variety of industrial and biological applications because of several useful properties like paramagnetism, semiconductivity and resistance to high energies [33,34].

Hence polymeric Schiff base ligands and their metal complexes have been applied as polymer catalysts [35,36], metallomesogens [37], supermolecular metal complexes [38]. While most of polymeric Schiff base ligands are used as drugs due to their excellent antimicrobial activity against various strains of bacterias, fungi and yeast. Along with this they are also found to be active as antiangiogenic and DNA-photoclevage agents. It seemed advantageous to prepare a polymeric-bound chelating ligand, which would be able to form complexes with variety of transition metals and hence increases its applications to many folds. In recent years, efforts have been made to synthesize a variety of polymeric coordination compounds to prevent microbial infections. The chelated metal ions increase the lipophillic nature of the compounds, which result its easier permeation to the lipid layer of the cell membrane. The metal ions coordinated to polymeric Schiff base also inhibit the bacterial cell for biosynthesis and affect protein synthesis because the metal could coordinate to active site to block the substrate [39]. These facts inspired us to synthesise new coordination polymer with adequate antimicrobial properties. Keeping all these things into consideration a new Schiff base ligand polymer (heptamer) has been prepared using condensation reaction between 3,4diacetyl-2,5-hexanedione and hydrazine hydrate which form a linear polymer (heptamer) and form transition metal complexes when react with transition metal ions like $\mathrm{Co}(\mathrm{II}), \mathrm{Cu}(\mathrm{II}), \mathrm{Ni}(\mathrm{II})$, $\mathrm{Fe}(\mathrm{II}), \mathrm{Zn}(\mathrm{II}), \mathrm{Cd}(\mathrm{II})$ and Ti(II). The synthesized Schiff base polymer and its metal complexes were studied for antimicrobial, antiangiogenic and DNA-photocleavage activities.

\section{EXPERIMENTAL}

All the chemicals used in synthesis were of A.R. grade and used as received without any further purification. Sodium metal was added to diethyl ether for $24 \mathrm{~h}$ before to use it so that moisture can be removed from it. All the chemical reactions for preparation of Schiff base were performed on magnetic stirrer equipped with a hot plate under stirring and all reactions to synthesize metal complexes were performed on water bath with water condenser. The ligand was purified with methanol before preparing metal complexes. NMR spectra were recorded on BRUKER AVANCE NMR-spectrophotometer at frequencies of $400 \mathrm{MHz}$ using TMS as internal reference standard. The $\mathrm{H}^{1}$ -chemical shifts are expressed in ppm. The melting point of raw material was determined using open capillary method. IR spectra were recorded on Perkin Elmer FT-IR Spectrometer in $4000-400 \mathrm{~cm}^{-1}$ range using $\mathrm{KBr}$ pellet method. Micro spectra for determining $\mathrm{C}, \mathrm{H}$ and $\mathrm{N}$ were performed using Perkin Elmer CHN Analyzer. Mass spectra were obtained on WATERS, QTOF MICROMASS (ESI-MS) mass spectrometer.

Preparation of Schiff base ligand: Schiff base ligand was prepared by condensation reaction between 3,4-diacetyl2,5-hexanedione and hydrazine hydrate. 3,4-Diacetyl-2,5hexanedione was prepared according to literature method [40] and hydrazine hydrate was procured from Merck and used as such without any further purification. To synthesize ligand, $1 \mathrm{~mol}(0.5 \mathrm{~g})$ of 3,4-diacetyl-2,5-hexanedione was mixed with $20 \mathrm{~mL}$ of ethanol. To this solution, $4 \mathrm{~mol}(0.5 \mathrm{~g})$ of hydrazine hydrate was added. The mixture was refluxed at $60^{\circ} \mathrm{C}$ for $2.5 \mathrm{~h}$. To maintain $\mathrm{pH}$, one drop of conc. $\mathrm{H}_{2} \mathrm{SO}_{4}$ was introduced in the mixture through condenser. The transparent liquid obtained was cooled down at room temperature. Some ice-cubes were added in the resulting solution. Fine white crystals were appeared after keeping the solution undisturbed for three days. The precipitated crystals were filtered from mother liquid and dried at room temperature to yield $2.3 \mathrm{~g}$ of colourless crystals (SchemeI). Elemental analysis calcd. (found) $\%$ for $\mathrm{C}_{70} \mathrm{H}_{108} \mathrm{~N}_{106} \mathrm{O}: \mathrm{C}$ 59.49 (59.46); H 7.64 (7.62); N 31.72 (31.67); O 1.13 (1.10). IR $\left(\mathrm{KBr}, v_{\max }, \mathrm{cm}^{-1}\right): 3174(\mathrm{~N}-\mathrm{H}), 3031(\mathrm{C}-\mathrm{H}), 3363(\mathrm{O}-\mathrm{H}), 1575$ $(\mathrm{C}=\mathrm{N}), 972(\mathrm{C}-\mathrm{H}) .{ }^{1} \mathrm{H}$ NMR $\left(600 \mathrm{MHz}, \mathrm{DMSO}-d_{6}\right) \delta \mathrm{ppm}$ : 7.0 (s, 2H, N-H), 2.0 (s, 3H, N=C-CH $\left.{ }_{3}\right), 1.2(\mathrm{~s}, 1 \mathrm{H}, \mathrm{C}-\mathrm{H})$. GCMS (m/z): 190, 693, 1366, 1412.

Preparation of Co(II) complex: The synthesized Schiff base ligand ( $1 \mathrm{~mol}, 1.4 \mathrm{mg}$ ) was dissolved in $20 \mathrm{~mL}$ ethanol.

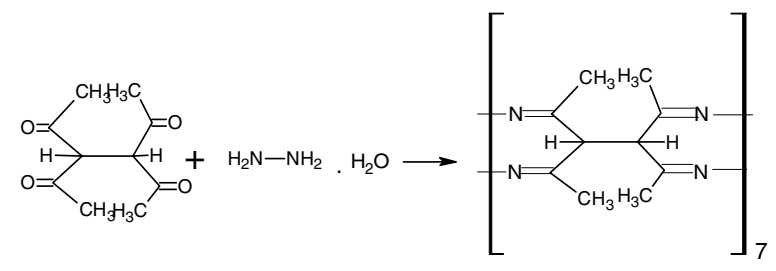

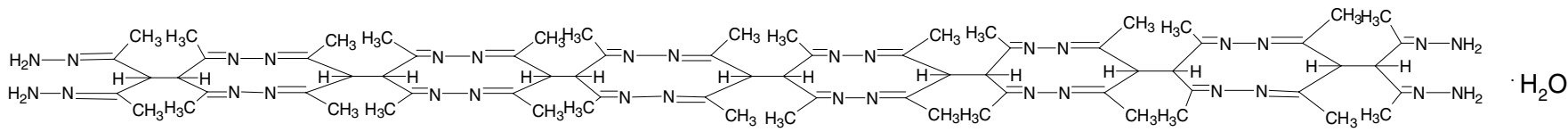

Scheme-I: Preparation of ligand 
To the resulting transparent solution, anhydrous cobalt(II) chloride (7 mol, $1.68 \mathrm{mg}$ ) was added (Scheme-II). The mixture was refluxed on a water bath for $2.5 \mathrm{~h}$ using a water condenser to complete the precipitation. The resulting precipitated mixture was cooled at room temperature, filtered and washed with ethanol and then again dried in vacuum desicator to yield $1.15 \mathrm{~g}$ violet coloured solid complex. Elemental analysis calcd. (found) $\%$ for $\mathrm{C}_{70} \mathrm{H}_{104} \mathrm{~N}_{106} \mathrm{Co}_{8} \mathrm{Cl}_{16}$ : C 35.16 (35.18); H 4.38 (4.35); $\mathrm{N} 18.86$ (18.85); Co 18.07 (18.09). IR (KBr, $\left.v_{\max }, \mathrm{cm}^{-1}\right): 3330(\mathrm{~N}-\mathrm{H})$, $2918(\mathrm{C}-\mathrm{H}), 1624(\mathrm{C}=\mathrm{N}), 441(\mathrm{M}-\mathrm{N}) .{ }^{1} \mathrm{H}$ NMR $(600 \mathrm{MHz}$, DMSO- $\left.d_{6}\right) \delta$ ppm: 7.1 (s $\left.2 \mathrm{H}, \mathrm{N}-\mathrm{H}\right), 2.2\left(\mathrm{~s}, 3 \mathrm{H}, \mathrm{N}=\mathrm{C}-\mathrm{CH}_{3}\right), 1.2$ (s, 1H, C-H).

Preparation of Ni(II) complex: The synthesized Schiff base ligand (1 mol, $1.4 \mathrm{mg}$ ) was dissolved in $20 \mathrm{~mL}$ ethanol. To the resulting transparent solution, anhydrous nickel(II) chloride ( $7 \mathrm{~mol}, 1.68 \mathrm{mg}$ ) was added. The mixture was then refluxed on a water bath for $2.5 \mathrm{~h}$ using a water condenser to complete the precipitation. The resulting precipitated mixture was cooled at room temperature, filtered and washed with ethanol and then again dried in vacuum desicator to yield $1.21 \mathrm{~g}$ light green coloured solid complex. Elemental analysis calcd. (found) $\%$ for $\mathrm{C}_{70} \mathrm{H}_{104} \mathrm{~N}_{106} \mathrm{Ni}_{8} \mathrm{Cl}_{16}$ : C 34.60 (34.63); $\mathrm{H} 4.33$ (4.32); N 18.48 (18.47); Ni 19.35 (19.34). IR ( $\left.\mathrm{KBr}, v_{\max }, \mathrm{cm}^{-1}\right)$ : $3321(\mathrm{~N}-\mathrm{H}), 2924(\mathrm{C}-\mathrm{H}), 1614(\mathrm{C}=\mathrm{N}), 444(\mathrm{M}-\mathrm{N}) .{ }^{1} \mathrm{H}$ NMR $\left(600 \mathrm{MHz}, \mathrm{DMSO}-d_{6}\right) \delta$ ppm: 7.3 (s $\left.2 \mathrm{H}, \mathrm{N}-\mathrm{H}\right), 2.1$ (s, $3 \mathrm{H}$, $\left.\mathrm{N}=\mathrm{C}-\mathrm{CH}_{3}\right), 1.3$ (s, $\left.1 \mathrm{H}, \mathrm{C}-\mathrm{H}\right)$.

\section{Antimicrobial activities}

Disc diffusion assay: in vitro Antimicrobial activity was evaluated for synthesized ligand and its transition metal complexes against pathogenic strains of bacteria such as $S$. aureus, $K$. pneumonia and fungi $A$. niger, $T$. rubrum, using disc plate diffusion assay. The stock solutions of ligand $(1000 \mu \mathrm{g} /$ $\mathrm{mL}$ ) were prepared in ethanol. The plates of culture medium using nutrient agar and potato-dextrose agar were prepared for bacterial and fungal growth respectively under sterilized condition. The various concentrations of ligand such as 100 , 150,200 and $250 \mu \mathrm{g} / \mathrm{mL}$ was loaded on $5 \mathrm{~mm}$ sterilized filter paper discs/or in well followed by incubation at $30^{\circ} \mathrm{C}$ for 24 and $72 \mathrm{~h}$ to evaluate the effect of compound on bacterial and fungal growth, respectively. Commercial antibiotic such as neomycin and fluconazole were used as standard antimicrobial agents for bacterial and fungal studies, respectively.

\section{Antiangeogenic activity}

Chorioallantoic membrane (CAM) assay: Antiangeogenic activity was evaluated using $e x$-vivo CAM assay. The fertilized chicken eggs was collected, cleaned with $70 \%$ ethanol to avoid infections and kept in a humidified $(70 \%)$ chamber at $37^{\circ} \mathrm{C}$. After $48 \mathrm{~h}, 1 \mathrm{~mL}$ of albumin was taken out with a syringe from the lower side of the eggs and the pierced holes were sealed with a sterilized laboratory tape. After $72 \mathrm{~h}$ of incubation, a small window was made by removing the egg shell at the blunt end. On confirmation of normal and viable development of the embryo, various concentrations of synthesized ligand ( 0 , 1 and $10 \mu \mathrm{g}$ ) was loaded on $5 \mathrm{~mm}$ sterilized filter discs and placed over the surface of extra embryonic membrane i.e. CAM. The windows were sealed with sterilized laboratory tape to prevent external environmental contact and eggs were kept for $48 \mathrm{~h}$ under incubation. After the treatment, antiangeogenic effect of ligand was manually counted in terms of branch points over CAM and the percent inhibition was calculated as follows:

$$
\text { Inhibition }(\%)=\frac{\text { Data of control }- \text { Data of treated }}{\text { Data of control }} \times 100
$$

DNA photo-cleavage assay: DNA cleavage activity of the synthesized ligands was studied by agarose gel electrophoresis using supercoiled DNA from plasmid such as pUC19 [41]. The total volume of reaction mixture was $10 \mu \mathrm{L}$ containing $0.5 \mu \mathrm{g}$ of plasmid DNA in TE (Tris $10 \mathrm{mM}$, EDTA $0.01 \mathrm{mM}$, $\mathrm{pH}$ 8.0) buffer with various concentrations of synthesized ligands. The eppendorfs carrying reaction mixture was placed directly on the surface of a trans-illuminator $(8000 \mathrm{~mW} / \mathrm{cm})$, at $360 \mathrm{~nm}$ for $30 \mathrm{~min}$. After irradiation, samples was further incubated at $37^{\circ} \mathrm{C}$ for $1 \mathrm{~h}$. Irradiated samples was mixed with $6 \mathrm{X}$ loading dye containing $0.25 \%$ bromophenol blue and $30 \%$ glycerol. Then the samples was analyzed by electrophoresis on a $0.8 \%$ agarose horizontal slab gel in Tris-acetate EDTA buffer (40 mM Tris, $20 \mathrm{mM}$ acetic acid, $1 \mathrm{mM}$ EDTA, pH: 8.0) with comparison to untreated plasmid DNA as a control. Gel was stained with ethidium bromide $(1 \mu \mathrm{g} / \mathrm{mL})$ and photographed under UV light.

\section{RESULTS AND DISCUSSION}

The synthesized Schiff base polymer (heptamer) appears to be colourless while it's transition metal complexes are intensely coloured. The solubility test for Schiff base and its metal complexes in different solvents, established their solubility in ethanol, DMSO and DMF. Both Schiff base and metal complexes were obtained in good yield. The spectroscopic and elemental analysis confirm the authenticity of the products. Hence, the structure of compounds established on the basis of IR, NMR and mass spectroscopy. The IR spectra of free ligand

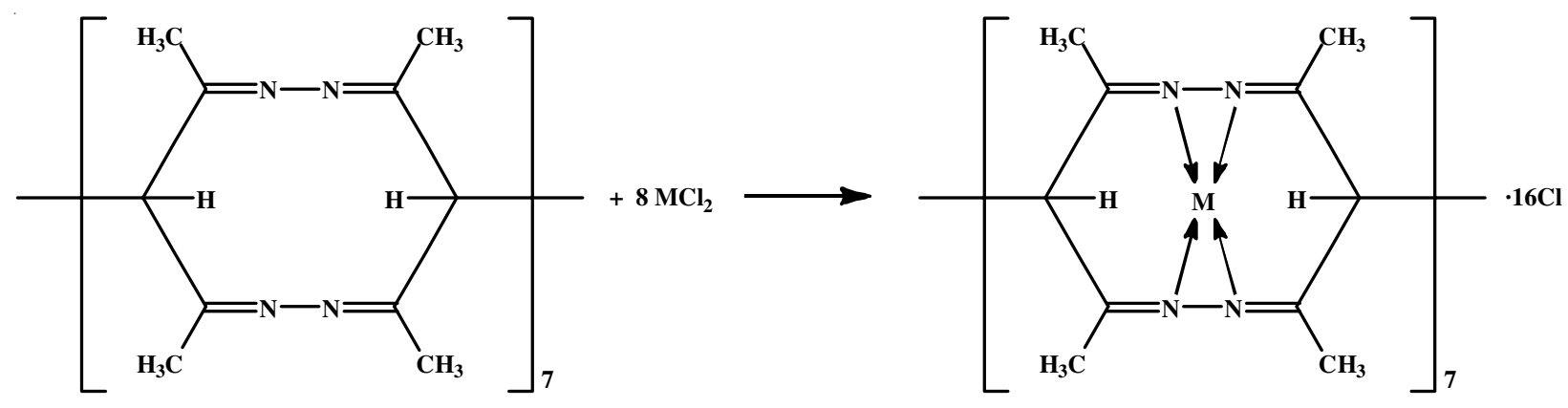

Scheme-II: Preparation of Ni and Co complex 
show a characteristic $v(\mathrm{~N}-\mathrm{H})$ peak at $3174 \mathrm{~cm}^{-1}$, which has been shifted to $3325-3240 \mathrm{~cm}^{-1}$ in case of the metal complexes. Band at $3363 \mathrm{~cm}^{-1}$ in the spectra of ligand attributed to $\mathrm{v}(\mathrm{O}-\mathrm{H})$. Absence of $v(C=O)$ peak at around $1700 \mathrm{~cm}^{-1}$ and appearance of strong peak at $1686-1582 \mathrm{~cm}^{-1}$ indicated a Schiff base condensation to form $(\mathrm{C}=\mathrm{N})$ linkage $[42,43]$. The IR spectra of all complexes shows strong peaks for $v(C=N)$ at 1643 $1541 \mathrm{~cm}^{-1}$ and it is found that $v(\mathrm{C}=\mathrm{N})$ band in the complexes are shifted by about $43-40 \mathrm{~cm}^{-1}$ to a lower energy compared to that in the free ligand. Absence of bands at $448-438 \mathrm{~cm}^{-1}$ in case of ligand and appearance in case of transition metal complexes shows the coordination between nitrogen and transition metal. Hence this phenomenon appears to be due to coordination of azomethine nitrogen to the metal ion [44]. 3,4-Diacetyl-2,5hexanedione is capable of exhibiting keto-enol tautomerization and react with metal cation to form complexes. The ${ }^{1} \mathrm{H}$ NMR shows a singlet at $\delta 2.0 \mathrm{ppm}$ due to three protons of methyl group [45], singlet at $\delta 7.0 \mathrm{ppm}$ [46] corresponds to imine proton, a weak singlet at $\delta 1.2 \mathrm{ppm}$ corresponds to single hydrogen of monomeric unit of polymer in Schiff base. While a clear appearance of spectra i.e. singlet at $\delta 2.80-3.10 \mathrm{ppm}$ for $-\mathrm{N}=\mathrm{C}-\mathrm{CH}_{3}$ [47], $\delta$ 9.0-9.5 ppm for imine proton [45], singlet at $\delta 1.52-1.63 \mathrm{ppm}$ for $-\mathrm{CH}$ protons [48] in all prepared complexes shows that all the signals get shifted downfield, hence it indicate the formation Schiff base metal complex and confirming coordination. The study of mass spectra of complexes with ligand play an important role in confirming the polymeric nature of the complexes. The MS peak is attributed ligand: $1412\left[\mathrm{C}_{70} \mathrm{~N}_{32} \mathrm{H}_{106}\right], 693\left[\mathrm{C}_{35} \mathrm{~N}_{16} \mathrm{H}_{49}\right], 190\left[\mathrm{C}_{10} \mathrm{~N}_{4} \mathrm{H}_{14}\right]$ (Scheme-III). The data is in good agreement with proposed molecular formula for prepared transition metal complexes. In addition to the peaks due to molecular ion, the spectra exhibited peaks assigned to various fragments arising from the thermal cleavage of the complexes. The peak intensity gives an idea of stability of the fragments.

\section{Biological activities}

Disc-diffusion assay: The antimicrobial activity of synthesized Schiff base polymer and its metal complexes was determined in vitro against bacteria and fungi. The activity was determined by measuring the diameter of zone of inhibition (mm). The diameter for each treatment ranged from 12-27 mm. The results have shown that Schiff base and their metal complexes exhibited moderate to high activity on growth of tested bacterial and fungal species when compared with common antibiotics like neomycin and fluconazole (Table-1). The antimicrobial

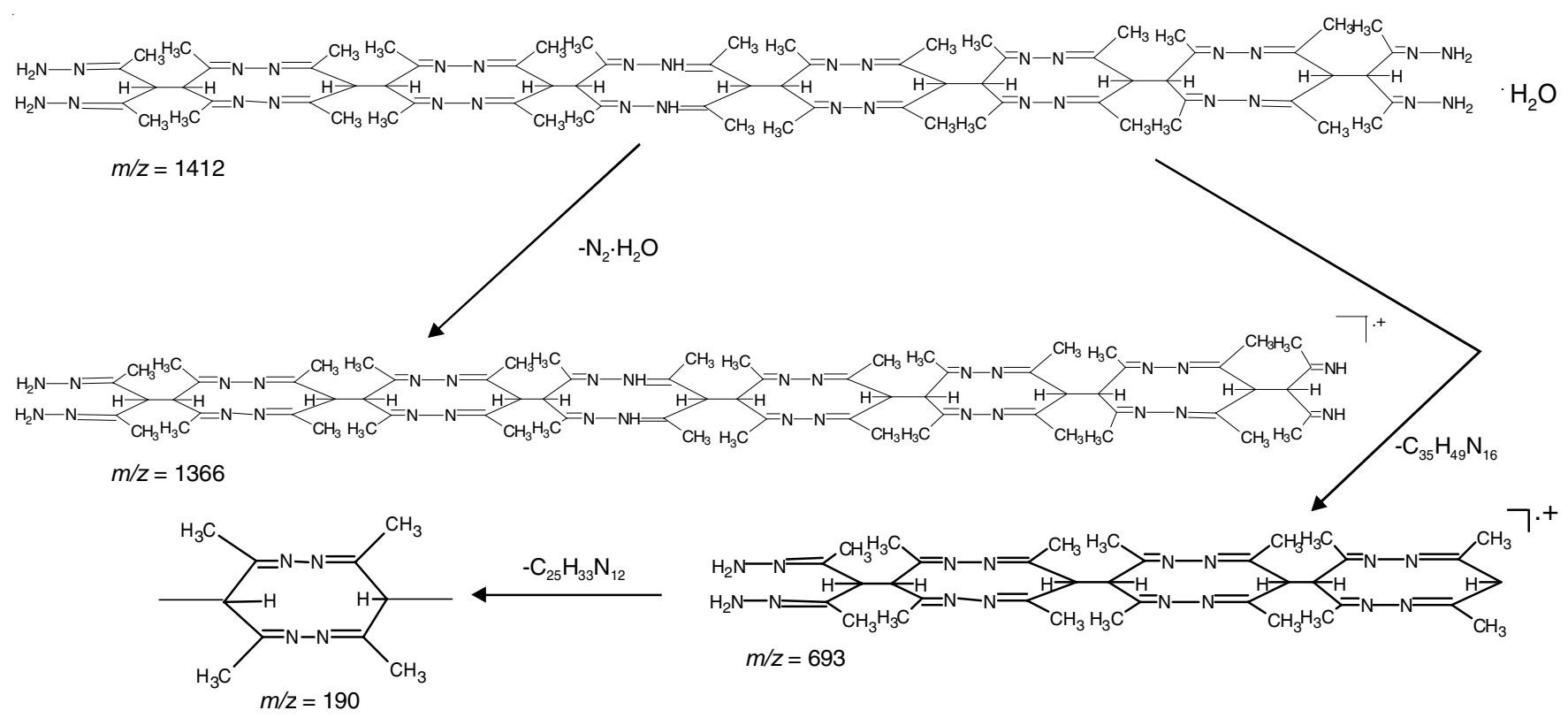

Scheme-III: Proposed mass fragmentation pattern of ligand

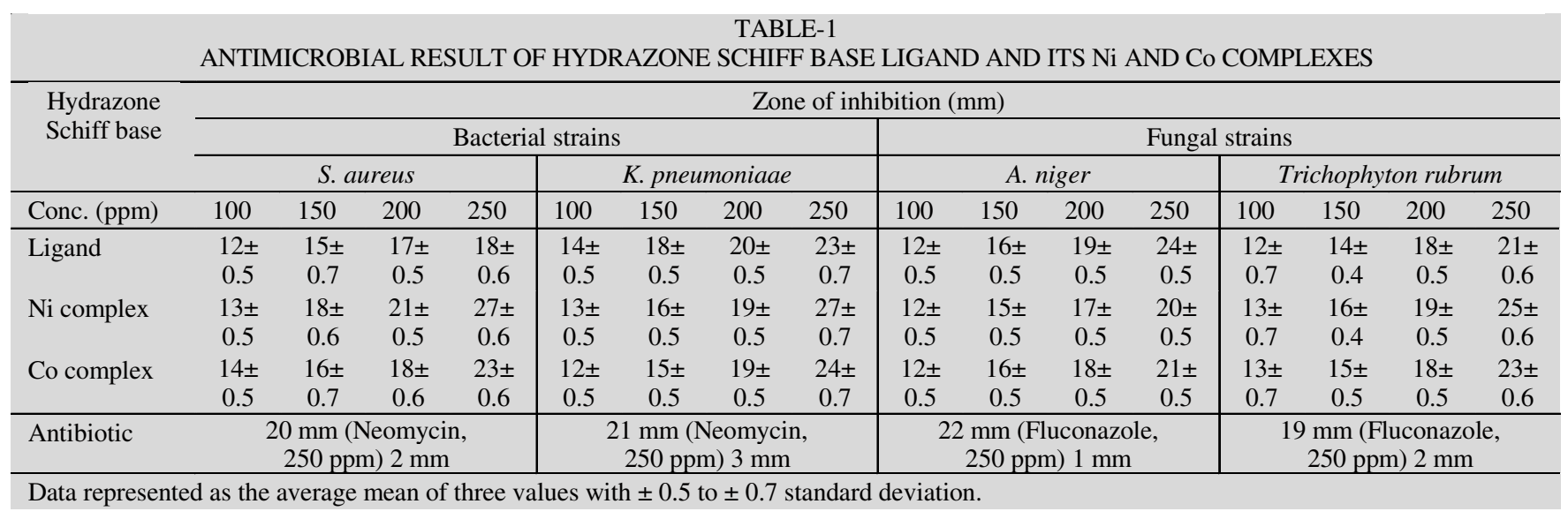


results evidently showed that the activity of metal complexes is higher than that of corresponding ligand, it means that chelation increases the antimicrobial activity.

Antiangeogenic activity using chorioallantoic membrane (CAM) assay: Antiangeogenic activity was evaluated for the prepared Schiff base and metal complexes using ex-vivo CAM assay. A scoring method was used to assess the level of antiangiogenic activity of compounds by counting total number of blood vessels or undeveloped blood vessels in terms of branch points over CAM. The significant differences were found in comparison to untreated control (Fig. 1).

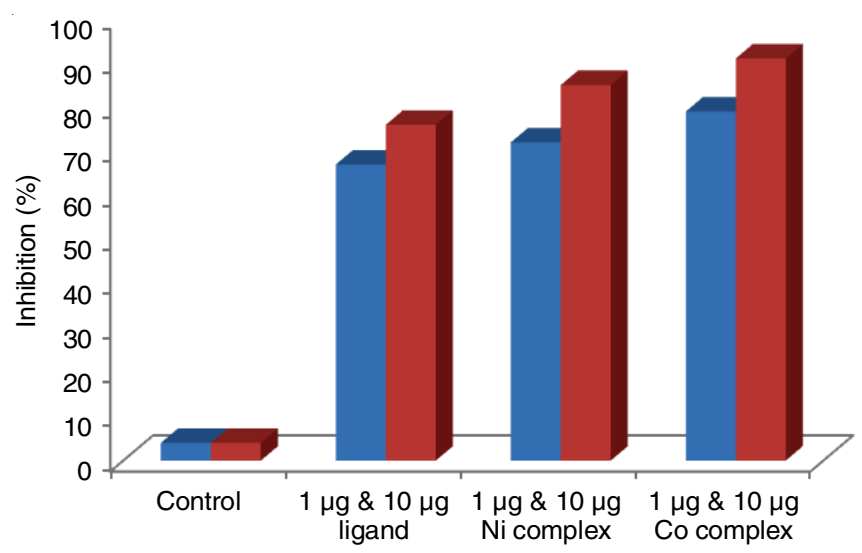

Fig. 1. Antiangeogenic activity of ligand and its $\mathrm{Ni}$ and Co complexes

DNA photo-cleavage assay: DNA cleavage activity of the synthesized ligands was studied by agarose gel electrophoresis using supercoiled DNA from plasmid such as pUC19 [42]. The results obtained after analysis suggested that the Schiff base and its transition metal complexes have DNA cleaving and binding potential. It has been observed that ligand and its metal complexes were able to convert super coiled plasmid DNA to open form (Fig. 2). Previously, Yernale and Mathada [49] have observed the promising DNA cleaving activity of hydrazinecarboxamide based Schiff base using plasmid DNA. Therefore, in near future novel DNA cleaving agent could play an important role in designing biological active drugs [50,51].

\section{Conclusion}

A novel Schiff base polymer and its complexes of Co(II), $\mathrm{Ni}(\mathrm{II})$ have been synthesized. The Schiff base ligand was synthesized by condensation reaction between 3,4-diacetyl-2,5-hexanedione and hydrazine hydrate with one drop of conc. $\mathrm{H}_{2} \mathrm{SO}_{4}$ in ethanol at $60^{\circ} \mathrm{C}$. After that transition metal complexes were prepared by reacting Schiff base ligand with metal(II) chlorides. The Schiff base and their metal complexes were characterized by IR, ${ }^{1} \mathrm{H}$ NMR and mass spectrometry. Mass spectra indicated the formation of a polymer (heptamer) and polymeric metal (II) complexes and IR, ${ }^{1} \mathrm{H}$ NMR spectra has confirmed it. The antimicrobial activity of Schiff base and its metal complexes showed that ligand and metal complexes acts as very good antimicrobial agents against various used species of bacteria and fungi as well as a potent anti-angiogenesis and DNA-photo cleavage agents.

\section{ACKNOWLEDGEMENTS}

The authors are thankful to Sophisticated Analytical Instrumentation Facility (SAIF), Punjab University, Chandigarh, India for providing the necessary instrumental support.

\section{CONFLICT OF INTEREST}

The authors declare that there is no conflict of interests regarding the publication of this article.

\section{REFERENCES}

1. S. Kumar, D.N. Dhar and P.N. Saxena, J. Sci. Ind. Res., 68, 181 (2009).

2. H.C. Aspinall, Chem. Rev., 102, 1807 (2002);

https://doi.org/10.1021/cr010288q.

3. K.L. Haas and K.J. Franz, Chem. Rev., 109, 4921 (2009);

https://doi.org/10.1021/cr900134a.

4. T. Rosu, S. Pasculescu, V. Lazar, C. Chifiriuc and R. Cernat, Molecules, 11, 904 (2006); https://doi.org/10.3390/11110904

5. S.K. Sridhar, S.N. Pandeya, J.P. Stables and A. Ramesh, Eur. J. Pharm. Sci., 16, 129 (2002); https://doi.org/10.1016/S0928-0987(02)00077-5.

6. M.C. Rodrìguez-Argüelles, M.B. Ferrari, F. Bisceglie, C. Pelizzi, G. Pelosi, S. Pinelli and M. Sassi, J. Inorg. Biochem., 98, 313 (2004); https://doi.org/10.1016/j.jinorgbio.2003.10.006.

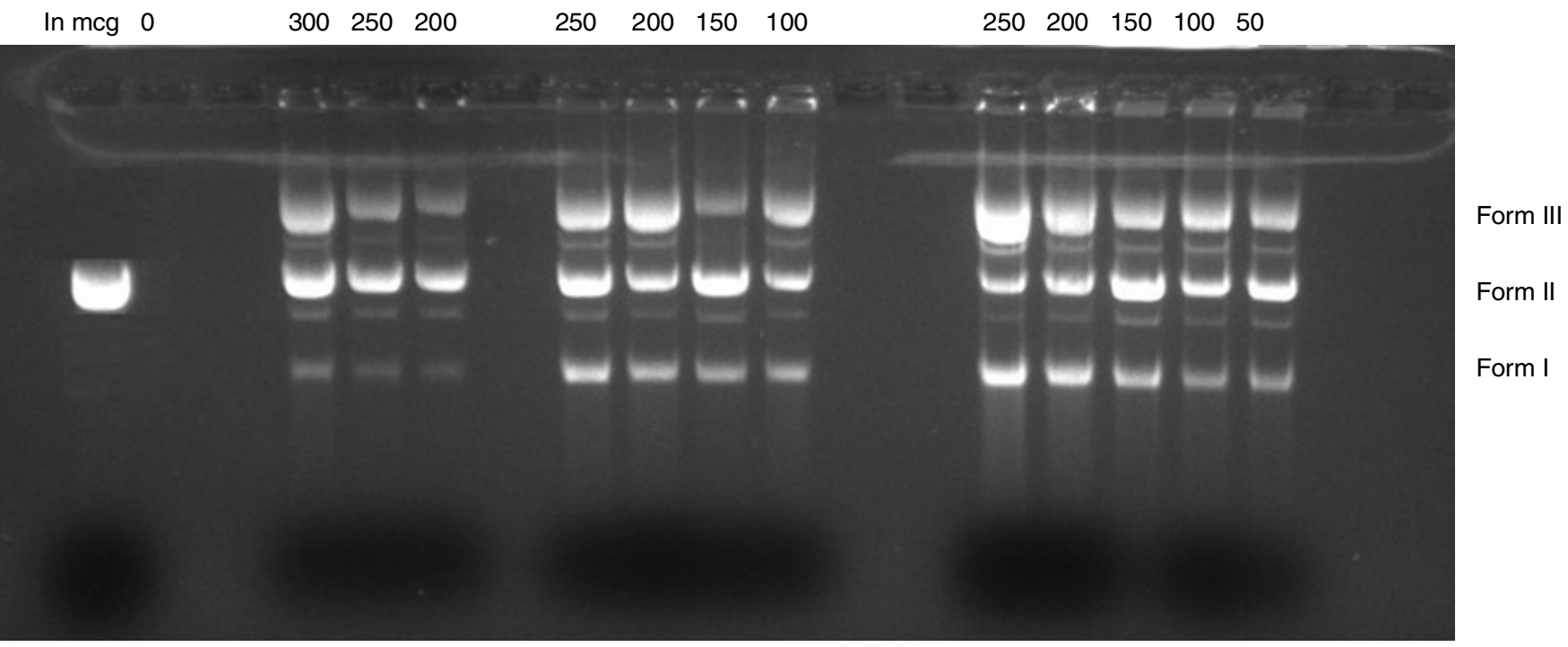

Fig. 2. DNA photo-cleavage of ligand and its transition metal complexes 
7. J.A. Sclafani, M.T. Maranto, T.M. Sisk and S.A. Van Arman, Org. J. Chem., 61, 3221 (1996); https://doi.org/10.1021/jo952190f.

8. R.N. Sharma, K.P. Sharma and S.N. Dikshit, J. Adv. Sci. Res., 2, 5 (2011).

9. D.R. Richardson and P.V. Bernhardt, J. Biol. Inorg. Chem., 4, 266 (1999); https://doi.org/10.1007/s007750050312.

10. M.T. Tarafder, A. Kasbollah, N. Saravan, K.A. Crouse, A.M. Ali and O.K. Tin, J. Biochem. Mol. Biol. Biophys., 6, 85 (2002).

11. R. Sahu, D.S. Thakur and P. Kashyap, Int. J. Pharm. Sci. Nanotechnol., 5, 1757 (2002)

12. P. Vicini, A. Geronikaki, M. Incerti, B. Busonera, G. Poni, C.A. Cabras and P. La Colla, Bioorg. Med. Chem., 11, 4785 (2003); https://doi.org/10.1016/S0968-0896(03)00493-0.

13. Z. Jaman, M.R. Karim, K. Dumenyo and A.H. Mirza, Adv. Microbiol., 4, 1140 (2014); https://doi.org/10.4236/aim.2014.415124.

14. R. Pignatello, A. Panico, P. Mazzone, M.R. Pinizzotto, A. Garozzo and P.M. Fumeri, Eur. J. Med. Chem., 29, 781 (1994); https://doi.org/10.1016/0223-5234(94)90137-6.

15. M.S. Yadawe and S.A. Patil, Transition Metal Chem., 22, 220 (1997); https://doi.org/10.1023/A:1018400121316.

16. N. Sinha, S. Jain, A. Tilekar, R.S. Upadhayaya, N. Kishore, G.H. Jana and S.K. Arora, Bioorg. Med. Chem. Lett., 15, 1573 (2005); https://doi.org/10.1016/j.bmcl.2005.01.073.

17. H.I. Boshoff, M.B. Reed, C.E. Barry 3rd and V. Mizrahi, Cell, 113, 183 (2003); https://doi.org/10.1016/S0092-8674(03)00270-8.

18. I.G. Darnel and D.R. Richardson, Blood, 94, 781 (1999).

19. B. Murukan and K. Mohanan, J. Enzyme Inhib. Med. Chem., 22, 65 (2007); https://doi.org/10.1080/14756360601027373.

20. R. Rasool, S. Hasnain and N. Nishat, J. Designed Monomers Polymers, 17, 217 (2014); https://doi.org/10.1080/15685551.2013.840472.

21. M.T.H. Tarafder, M.A. Ali, N. Saravanan, W.Y. Weng, S. Kumar, N. Umar-Tsafe and K.A. Crouse, Transition Metal Chem., 25, 295 (2000); https://doi.org/10.1023/A:1007044910814.

22. A. Jarrahpour, D. Khalili, E. DeClercq, C. Salmi and J.M. Brunel, Molecules, 12, 1720 (2007); https://doi.org/10.3390/12081720.

23. S.N. Pandeya, D. Sriram, G. Nath and E. DeClercq, Eur. J. Pharm. Sci., 9, 25 (1999); https://doi.org/10.1016/S0928-0987(99)00038-X.

24. R.M. Mohareb and A.A. Mohamed, Molecules, 15, 3602 (2010); https://doi.org/10.3390/molecules15053602.

25. A. Hills, D.L. Hughes, G.J. Leigh and J.R. Sanders, J. Chem. Soc., Dalton Trans. II, 325 (1991); https://doi.org/10.1039/DT9910000325.

26. R. Knoch, A. Wilk, K.J. Wannowius, D. Reinen and H. Elias, Inorg. Chem., 29, 3799 (1990); https://doi.org/10.1021/ic00344a030.

27. L. Carbonaro, A. Giacomelli, L. Senatore and L. Valli, Inorg. Chim. Acta, 165, 197 (1989); https://doi.org/10.1016/S0020-1693(00)83239-9.
28. A. Bajpai, S. Rai and U.D.N. Bajpai, Polym. J., 29, 44 (1997); https://doi.org/10.1295/polymj.29.44.

29. K. Takagi, I. Tomita and T. Endo, Macromolecules, 30, 7386 (1997); https://doi.org/10.1021/ma9708959.

30. M.D. Hobday and T.D. Smith, Coord. Chem. Rev., 9, 83 (1973); https://doi.org/10.1016/S0010-8545(00)82081-0.

31. L.F. Lindoy, Q. Rev. DC Nurses Assoc., 25, 379 (1971); https://doi.org/10.1039/qr9712500379.

32. M. Cieslak-Golonka, A. Bartecki and S.P. Sinha, Coord. Chem. Rev., 31, 251 (1979); https://doi.org/10.1016/S0010-8545(00)80451-8.

33. S.C. Suh and S.C. Shim, Synth. Met., 114, 91 (2000); https://doi.org/10.1016/S0379-6779(00)00234-4

34. B.A.M. Amedov, Y.A. Vidadi, D.N. Alieva and A.V. Ragimov, Polym. Int., 43, 126 (1997); https://doi.org/10.1002/(SICI) 1097-0126(199706)43:2<126::AIDPI723>3.0.CO;2-\%23.

35. M. Kimura, H. Shirai, K. Takemoto, R.M. Ottenbrite and M. Kamachi, Functional Monomers and Polymers, Marcel Dekker Inc.: New York, vol. 2, p. 552 (1997).

36. E.A. Bekturov and S.E. Kudaibergenov, Catalysis of Polymers, H. Huttig-Werf, p. 180 (1996).

37. D.W. Bruce, eds.: D.W. Bruce and D. O'Hare, Inorganic Materials, John Wiley \& Sons: Chichester, p. 405 (1992).

38. J.P., Sauvage, Perspectives in Supramolecular Chemistry, In: Transition Metals in Supramolecular Chemistry, John Wiley \& Sons: Chichester, vol. 5 (1999).

39. A.Y. Louie and T.J. Meade, Chem. Rev., 99, 2711 (1999); https://doi.org/10.1021/cr9804285.

40. R.G. Charles, Org. Synth., 39, 61 (1959); https://doi.org/10.15227/orgsyn.039.0061.

41. Y. Liu, H. Chao, L. Tan, Y. Yuan, W. Wei and L. Ji, J. Inorg. Biochem., 99, 530 (2005); https://doi.org/10.1016/j.jinorgbio.2004.10.030.

42. W.D. Charity, P.E. Ikechukwu, M.M. Fanyana, J.K. Michael and D.D. Ezekiel, Int. J. Pharm. Pharmaceut. Sci., 9, 975 (2017).

43. D. Nasrin, M.A. Alam, M.N. Hossain and M. Nazimuddin, Chem. J., 3, 13 (2013)

44. L.J. Bellamy, The Infrared Spectra of Complex Molecules, John Wiley \& Sons: New York (1971).

45. V. Pawar, S. Joshi and V. Uma, Nigerian Soc. Exp. Biol., 23, 21 (2011).

46. F.A. Beckford, M.B. Niece, B.P. Lassiter, S.J. Beebe and A.A. Holder, J. Biol. Inorg. Chem., 23, 1205 (2018); https://doi.org/10.1007/s00775-018-1599-8.

47. S. D. Dakore, V.T. Kamble and P. Pisal, Int. J. Chem. Stud., 110, 2349 (2017).

48. V.K. Durg, Int. J. Pharm. Chem. Biol. Sci., 5, 77 (2015).

49. N.G. Yernale and M.B.H. Mathada, Bioinorg. Chem. Appl., 2014, Article ID 314963 (2014); https://doi.org/10.1155/2014/314963.

50. W. Hassan, R.A. Umar and M. Lawal, Breast J., 3, 18 (2006).

51. S. Dhar, D. Senapati, P.K. Das, P. Chattopadhyay, M. Nethaji and A.R. Chakravarty, J. Am. Chem. Soc., 125, 12118 (2003); https://doi.org/10.1021/ja036681q. 